\title{
PENGUKURAN KUALITAS LAMAN WEBSITE UNIVERSITAS DHYANA PURA MENGGUNAKAN METODE WEBQUAL 4.0
}

\author{
Gabriel Firsta Adnyana ${ }^{1)}$ Agus Tommy Adi Prawira Kusuma ${ }^{2)}$ \\ Program Studi Teknik Informatika ${ }^{1)}$ Program Studi Sistem Informasi ${ }^{2)}$ \\ Universitas Dhyana Pura \\ Gabrieladnyana89@undhirabali.ac.id ${ }^{1)}$ agustommyadi@undhirabali.ac.id ${ }^{2)}$
}

\begin{abstract}
Website is a form of electronic media that is published through an internet network connection that can be accessed without knowing the time and place. The website www.undhirabali.ac.id is a website that provides news information about academic activities in the form of teaching and learning activities (KBM). However, the problem that occurs so far is that there are still problems in terms of quality of use such as search content (searching) does not function properly, from the quality of information the existence of news content that is rarely updated, from the quality of service interactions such as the number of old news that is not found can be accessed. To find out the quality of a Website it is necessary to measure. By measuring the quality of a Website, it can be known the user's perception of the Website. There are 4 (four) main dimensions of WebQual 4.0, namely Usability, Information Quality, Service Interaction, and Overal Impression. WebQual Method 4.0. is an instrument that assesses the quality of a website according to the perspective of the end user. This research was conducted at the University of Dhyana Pura Badung-Bali. This research was conducted using a questionnaire and the data collection method used was random sampling. The population of this research is lecturers, students and administrative staff. In this study, the testing method used to test the relationship between variables from Webqual 4.0 to user satisfaction is the quantitative descriptive method approach by means of Chi Square testing. From the results of the study it can be concluded that the best quality of use is that the website provides clear interaction while the worst is that the website has no competition, then the best quality of information is providing a reliable website while the worst is the website does not provide detailed information and the best quality of service interaction that is website provides security while the worst is that website does not provide convenience to deliver feedback and the four variables Webqual 4.0, namely quality of use, quality of information and quality of service interaction have a positive and significant effect on user satisfaction (user satisfaction).
\end{abstract}

Keywords: Webqual, Website, Information Services, Random Sampling and Teaching and Learning Activities (KBM).

\begin{abstract}
ABSTRAK
Website merupakan salah satu bentuk media elektronik yang dipublikasi melalui koneksi jaringan internet yang dapat diakses tanpa mengenal waktu dan tempat. Website www.undhirabali.ac.id merupakan website yang memberikan pelayanan informasi berita seputar kegiatan akademik berupa kegiatan belajar mengajar (KBM). Namun permasalahan yang terjadi selama ini yaitu masih terdapat masalah dari segi kualitas kegunaan seperti konten pencarian (searching) tidak berfungsi dengan baik, dari kualitas informasi adanya konten-konten berita yang jarang diupdate, dari kualitas interaksi pelayanan seperti banyaknya ditemukan berita-berita lama yang tidak bisa diakses. Untuk mengetahui kualitas sebuah Website maka perlu dilakukan pengukuran. Dengan melakukan pengukuran kualitas suatu Website dapat diketahui persepsi pengguna terhadap Website tersebut. Terdapat 4 (empat) dimensi utama WebQual 4.0, yaitu Usability, Information Quality, Service Interaction, dan Overal Impression. Metode WebQual 4.O. merupakan instrument yang menilai kualitas suatu website menurut perspektif pengguna akhir. Penelitian ini dilakukan di lingkungan Universitas Dhyana Pura Badung-Bali. Penelitian ini dilakukan dengan menggunakan kuesioner dan metode pengambilan data yang digunakan adalah random sampling. Populasi dari penelitian ini adalah dosen, mahasiswa dan tenaga administrasi. Dalam penelitian ini, metode pengujian yang digunakan untuk menguji hubungan antar variabel dari
\end{abstract}


Webqual 4.0 terhadap kepuasan pengguna (user satisfaction) adalah dengan pendekatan metode deskriptif kuantitatif yaitu dengan cara pengujian Chi Square. Dari hasil penelitian dapat disimpulkan bahwa kualitas kegunaan yang paling baik yaitu website menyediakan interaksi yang jelas sedangkan yang paling buruk yaitu website tidak memiliki kompetisi, kemudian kualitas informasi yang paling baik yaitu menyediakan website yang dapat dipercaya sedangkan yang paling buruk yaitu website tidak menyediakan informasi yang detail serta kualitas interaksi pelayanan yang paling baik yaitu website memberikan keamanan sedangkan yang paling buruk yaitu website tidak memberikan kemudahan untuk menyampaikan umpan balik (feedback) dan keempat variabel Webqual 4.0, yaitu kualitas kegunaan, kualitas informasi dan kualitas interaksi pelayanan berpengaruh positif dan signifikan terhadap kepuasan pengguna (user satisfaction).

Kata Kunci: Webqual, Website, Layanan Informasi,Random Sampling dan Kegiatan Belajar Mengajar (KBM).

\section{PENDAHULUAN}

Website atau situs internet merupakan kumpulan halaman yang berisi dan menampilkan informasi data berupa teks, gambar baik statis atau dinamis, animasi, suara, video atau gabungan keseluruhannya [1]. Datadata tersebut membentuk serangkaian bentuk yang satu sama lain saling berkaitan dengan jaringan - jaringan halaman atau hyperlink. World Wide Web (www atau web) di internet telah meningkat secara dramatis dalam beberapa tahun terakhir. Khususnya potensi website sebagai media komersial secara luas diakui.

Perguruan tinggi membuat situs untuk mengenalkan dan mempromosikan lembaga pendidikannya. Pembuatan situs Perguruan Tinggi mempunyai tujuan diantaranya adalah untuk memberikan informasi mengenai profil, program akademis, sarana dan fasilitas, kegiatan yang telah dan akan berlangsung, capaian yang telah diperoleh dan lain sebagainya [2]. Dengan adanya situs memudahkan pengguna untuk mendapatkan informasi tanpa harus datang langsung ke lokasi.

Berdasarkan situs statshow.com mencatat jumlah pengunjung yang mengakses website undhirabali.ac.id sebanyak 45.260 orang pertahun [3]. Ditemukan beberapa permasalahan yaitu website kurang populer dari website beberapa Universitas yang ada di Bali. Saat ini website undhirabali.ac.id terdapat pada urutan ke 14.320 di Indonesia jauh tertinggal dari website beberapa universitas lainnya di bali [4]. Akibatnya pengguna atau user website kesulitan mendapatkan informasi yang lengkap dan update terkait berita dari setiap konten yang disediakan, dan juga pihak manajemen kesulitan menjalin kerjasama dengan instansi lain karena rating websitenya yang masih rendah. Kemudian ditemukan konten berita yang jarang di update, Akibatnya pengguna/user website kesulitan untuk mendapatkan informasi yang lengkap dan update terkait berita dari setiap konten yang disediakan, sehingga menyebabkan berkurangnya minat pengunjung untuk membuka website. Selanjutnya banyak ditemukan berita-berita lama yang tidak bisa dibuka lagi yaitu berita yang di publikasi.

Berdasarkan permasalahan diatas diperlukan pengukuran terhadap kualitas website Universitas Dhyana Pura Bali. Pengukuran ini diperlukan sebagai bahan pertimbangan bagi pimpinan untuk mengembangkan website berita mereka. Sehingga nantinya akan banyak menarik loyalitas pengunjung. Pada penelitian ini penulis menggunakan metode Webqual 4.0. Karena metode Webqual 4.0 telah banyak digunakan oleh peneliti terdahulu untuk mengukur suatu kualitas website. Kualitas website telah menjadi salah satu isu strategis dalam komunikasi dan transaksi dengan pelanggan/pengguna. Webqual merupakan salah satu metode pengukuran kualitas website yang dikembangkan oleh Stuart Barnes dan Richard Vidgen. Webqual berdasarkan pada konsep Quality Fuction Deployment (QFD) yaitu suatu proses yang berdasarkan pada "voice of costumer" dalam pengembangan dan implementasi suatu produk atau jasa [5]. Dari konsep QFD tersebut, Webqual disusun berdasarkan pada persepsi pengguna akhir (end user) terhadap suatu website. 
Beberapa penelitian yang pernah dilakukan untuk mengukur kualitas laman website dengan metode webqual dengan judul jurnal "Laman Quality: Case Study on Local Goverment Bank and State Own Bank in Bekasi City" [6], dan "Evaluating Wap News Sites: The Webqual/M Approach" [5], penelitian "Benchmark Laman Bhineka.Com Dan Eleveneia.Co.Id Dengan Metode Webqual". dengan jurnal berjudul "Analisis Kualitas Laman Menggunakan Metyode WebQual dan Importance - Performance Analysis (IPA), "Pengukuran kualitas website dengan menggunakan metode Webqual" [7].

Beberapa peneliti pernah meneliti tentang pengaruh metode webqual terhadap suatu website, namun penelitian yang pernah dilakukan yang berkaitan dengan pengukuran kualitas website itu hanya membandingkan suatu kualitas dari halaman website dan mempelajari tentang perilaku dari konsumen terhadap penggunaan website. Berdasarkan hal tersebut peneliti tertarik untuk meneliti tentang pengukuran kualitas halaman website Universitas Dhyana Pura Bali.

\section{TINJAUAN PUSTAKA Definisi Kualitas}

Kotler (2000) mengatakan bahwa, "Qualitiy is the totality of features and characteristics of a product or service that bear on its ability to satisfy stated or implied needs". Artinya kualitas adalah totalitas fitur dan karakteristik yang membuat produk mampu memuaskan kebutuhan, baik yang dinyatakan maupun yang tidak dinyatakan. Sedangkan Pahan (1998) mendefinisikan kualitas adalah gambaran dan karakteristik menyeluruh dari barang dan jasa yang menunjukan kemampuannya dalam memuaskan hubungan yang ditentukan atau tersirat. Sedangkan definisi yang dirumuskan oleh Goetsh dan Davis (1994) menyatakan bahwa kualitas merupakan suatu kondisi dinamis yang berhubungan dengan produk, layanan, manusia, proses, lingkungan yang memenuhi atau melebihi harapan. Penjelasan lengkap perihal definisi kualitas adalah pendapat David (1988), menurutnya kualitas dibagi menjadi 9 (sembilan) dimensi. Adapun ke-9 dimensi kualitas meliputi:
- Performance, karakteristik utama produk, misalnya gambar jernih pada layar televisi.

- Features, karakteristik tambahan, fasilitas atau fitur tambahan, misalnyaremote control.

- Conformance, spesifikasi industri dan standar industri

- Reliability, konsistensi kerja

- Durability, masa daya kegunaan / ketahanan produk, mencakup masa garansi dan perbaikan.

- Service, pertanggungjawaban atas permasalahan-permasalahan produk dan berbagai keluhan konsumen terhadap produk.

- Response, hubungan produsen-konsumen, termasuk peranan dealer.

- Aesthetics, berbagai kakarteristik yang berhubungan dengan psikologis produsen, penyalur/dealer, dan konsumen.

\section{Pengertian Laman}

Menurut Hidayat (2010) laman dapat diartikan sebagai kumpulan halaman-halaman web yang digunakan untuk menampilkan informasi teks, gambar diam atau gerak, animasi, suara, dan atau gabungan dari semuanya, baik yang bersifat statis maupun dinamis yang membentuk satu rangkaian bangunan yang saling terkait, yang masingmasing dihubungkan dengan jaringan-jaringan halaman. Hubungan antara satu laman dengan laman yang lainnya disebut Hyperlink, sedangkan teks yang dijadikan media penghubung disebut Hypertext.

\section{Pengukuran Kualitas Suatu Laman}

Ada lima kriteria untuk mengukur suatu laman, yaitu ketepatan (accuracy), sumber (authority), tujuan (objectivity), peredaran (currency), dan ulasan berita (coverage) (Kapoun, 1998).

\section{WebQual}

WebQual merupakan metode pengukuran kualitas laman berdasarkan persepsi pengguna akhir (masyarakat). Metode ini merupakan pengembangan dari Servqual (Zeithaml, 1990) yang banyak digunakan sebelumnya pada pengukuran kualitas jasa (Diana 2012).Instrumen penelitian pada WebQual tersebut dikembangkan dengan metode QFD yang bermakna : Terstruktur dan proses disiplin yang memberikan makna untuk 
mengidentifikasi dan membawa suara pelanggan melalui tiap-tiap tahap dari produksi atau pengembangan dan penerapannya (Slabey, 1990).

Menurut Kim dan Eom (2002) dalam Barnes dan Vidgen (2003), kualitas laman (WebQual) didasari dari metode QFD. Aplikasi dari QFD dimulai dengan menemukan "suara dari konsumen" dengan kata lain menemukan kebutuhan kualitas sesuai dengan keinginan konsumen. Kualitasyang diminta konsumen ini kemudian menjadi evaluasi terhadap suatu produk atau pelayanan. WebQual dibuat untuk mempelajari karakteristik atau fitur sebuah laman.

Menurut Loiciano, Watson dan Goodhue (2007). WebQual terdiri dari 12 dimensi, antara lain informasi yang sesuai, topik yang sesuai, informasi bisa dipercaya, waktu merespon, mudah dimengerti, pengoperasian yang intuitif, tampilan yang menarik, inovatif, punya daya tarik secara emosional, tampilan gambar yang konsisten, lengkap dan bisa berguna.

WebQual mulai dikembangkan sejak tahun 1998 dan dalam perkembangannya telah mengalami beberapa iterasi dalam penyusunan dimensi dan butir-butir pertanyaanya. WebQual disusun berdasarkan penelitian dari empat area, yaitu (1) kualitas pengguna, (2) kualitas informasi dari penelitian sistem informasi, (3) kualitas interaksi dan kualitas layanan dari penelitian kualitas sistem informasi, serta (4) kualitas dari keseluruhan atribut. Metobe WebQual saat ini merupakan salah satu metode yang paling baik digunakan untuk mengukur kualitas dari suatu laman.

WebQual 4.0 disusun berdasarkan penelitian yang terdiri atas empat dimensi area, yaitu:

Kualitas Penggunaan (Usability dari human computer interaction)

Usability adalah mutu yang berhubungan dengan rancangan halaman laman, sebagai contoh penampilan, kemudian pengguna, navigasi dan gambaran yang akan disampaikan ke pengguna (Barnes dan Vidgen; 2002 didalam Tarigan, 2008). Kualitas pengunaan meliputi, kemudahan dimengerti, kemudahan untuk ditelusuri, kemudahan untuk digunakan, sangat menarik, menampilan bentuk visual yang menyenangkan, memiliki kompetensi yang baik, memberikan pengalaman baru yang menyenangkan.

\section{Kualitas Informasi dari Penelitian Sistem Informasi (Information Quality) \\ Information Quality adalah mutu dari} isi yang terdapat pada laman, sesuai atau tidaknya informasi untuk tujuan pengguna seperti akurasi, format dan keterkaitannya (Barnes dan Vidgen; 2002 didalam Tarigan, 2008). Kualitas informasi meliputi hal-hal seperti informasi yang akurat, informasi yang bisa dipercaya, informasi yang terbaru, informasi yang sesui dengan topik bahasan, informasi yang mudah dimengerti, informasi yang sangat detail, dan terakhir informasi yang disajikan dalam format desain yang sesuai (Bames, 2003).

Kualitas Interaksi dan Kualitas Layanan dari Peneliti Kualitas Sistem Informasi (Service Interaction Quality)

Service Interaction Qualityadalah mutu dari interaksi pelayanan yang dialami oleh pengguna ketika mereka menyelidiki laman web lebih dalam. Sebagai contoh, isu dari keamanan transaksi dan informasi, pengantaran produk, personalisasi dan komunikasi dengan pemilik laman (Barnes dan Vidgen; 2002 didalam Tarigan, 2008). Kualitas interaksi meliputi kemampuan memberi rasa aman saat transaksi, memiliki reputasi yang bagus, memudahkan komunikasi, menciptakan perasaan emosional yang lebih personal, memiliki kepercayaan dalam menyimpan informasi pribadi pengguna, mampu menciptakan komunitas yang lebih spesifik, mampu memberikan keyakinan bahwa janji yang disampaikan akan akan ditepati.

\section{Kualitas Keseluruhan (Overall Impression)}

Penelitian kualitas dari keseluruhan ketiga kualitas di atas. Persepsi pengguna tersebut terdiri dari dua bagian, yaitu persepsi tentang mutu layanan yang dirasakan (aktual) dengan tingkat harapan (ideal). Barnes dan Vidgen (2003) melakukan penelitian dengan judul "An Integrative Approach to the Assessment of E-Commerce Quality" yang menggunakan WebQual untuk mengukur kualitas laman. 


\section{METODOLOGI PENELITIAN}

Berdasarkan pemodelan Website Quality (WebQual), terdapat tiga dimensi kualitas website yang selanjutnya akan dipakai sebagai Variabel Bebas. Tiga dimensi kualitas website, yaitu :

1. Variabel X1 adalah dimensi Kualitas Penggunaan (Usability Quality)

2. Variabel X2 adalah dimensi Kualitas Informasi (Information Quality)

3. Variabel X3 adalah dimensi Interaksi Service (Service Interaction)

Sementara Variabel Terikat (Y) adalah kepuasan pengguna (User Satisfation). Oleh karena itu, model konseptual penelitian ini dapat dilihat pada gambar berikut:

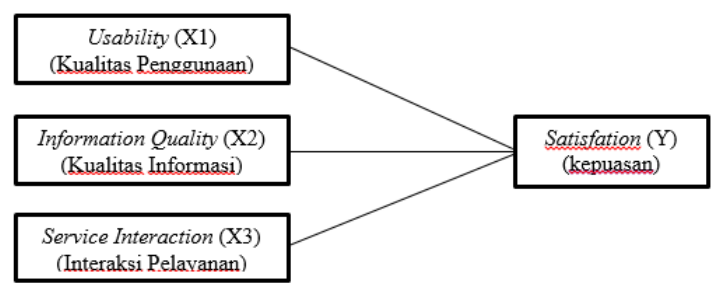

Gambar 1. Kerangka Konseptual Penelitian

\section{TAHAPAN PENELITIAN}

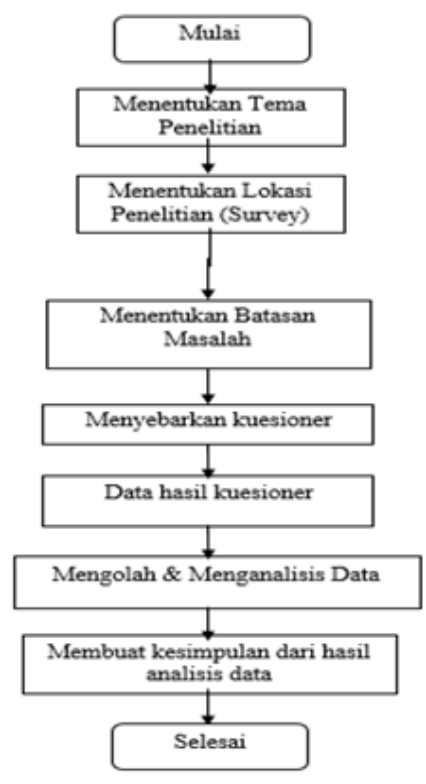

Gambar 2. Desain Penelitian

\section{Prosedur Pengumpulan Data}

Pengumpulan data dan informasi yang akan dilakukan di dalam penelitian ini terdiri atas data kuantitatif dan data kualitatif:

a. Data kuantitatif

Data dalam penelitian ini adalah data hasil kuesioner yang telah diberi angka pada masing-masing jawaban yang diperoleh dari penyebaran kuesioner dan karakteristik responden.

b. Data kualitatif

Data dalam penelitian ini adalah karakteristik responden yang meliputi nama, jenis kelamin, status perkawinan dan tingkat pendidikan.

Berdasarkan sumbernya data dalam penelitian ini terdiri dari data primer dan data sekunder.

a. Data primer dalam penelitian ini diperoleh melalui penyebaran kuesioner kepada responden yang telah sesuai dengan kriteria yang ditetapkan.

b. Data sekunder dalam penelitian ini diperoleh melalui pengumpulan data yang dilakukan dengan melakukan pengamatan langsung, dokumentasi terhadap publikasi dan sumber lainnya.

\section{Populasi dan Sampel Penelitian}

Populasi dalam penelitian ini adalah dosen, tenaga administrasi serta mahasiswa dari Universitas Dhyana Pura Bali. Jumlah indikator yang digunakan pada penelitian ini adalah 24 , maka banyaknya responden sebagai sampel antara 120 sampai 240 orang responden. Penelitian ini menggunakan 150 orang responden, sedangkan teknik pengambilan sampel menggunakan random sampling.

\section{HASIL DAN PEMBAHASAN Hasil Uji Reliabilitas Data}

Pengukuran uji reliabilitas dilakukan dengan perangkat lunak SPSS versi 17 dengan metode Cronbach Alpha, di mana menurut Malhotra (1998) dan Solimun (2002), bahwa suatu instrumen dikatan reliabel manakala memenuhi standar koefisien Cronbach Alpha lebih besar dari 0,4 (a>0.4). Dari hasil pengukuran reliabilitas dimana $\mathrm{N}=23$ (jumlah pertanyaan) didapatkan nilai Cronbach Alpha sebesar 0,481 ini berarti instrumen penelitian ini memenuhi syarat untuk dinyatakan reliabel yang hasilnya ditampilkan pada tabel 1 . 
Tabel 1. Hasil Uji Reabilitas Data

Case Processing Summary

\begin{tabular}{rlr|r} 
& & \multicolumn{1}{c}{ N } & \multicolumn{1}{c}{$\%$} \\
\hline \multirow{2}{*}{ Cases } & Valid & 150 & 100.0 \\
\cline { 2 - 4 } & Excluded $^{2}$ & 0 & .0 \\
\cline { 2 - 4 } & Total & 150 & 100.0 \\
\hline
\end{tabular}

a. Listwise deletion based on all variables in the procedure.

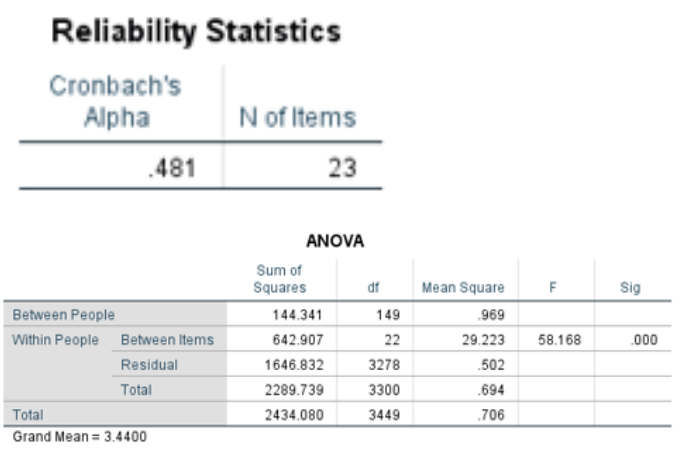

\section{Uji Chi Square}

Uji Crosstab adalah suatu mode analisis berbentuk tabel yang digunakan untuk

mengidentifiasi dan mengetahui apakah ada korelasi atau hubungan antara satu variabel dengan variabel yang lain. Dapat dikatakan analisis uji Crosstab merupakan metode untuk mentabulasikan beberapa variabel yang berbeda ke dalam satu matriks. Tabel yang dianalisis di sini adalah hubungan antara variabel dlam baris dengan variabel dalam kolom.

Tabel silang (Crosstab) dalam penelitian ini dilakukan terhadap lima dimensi yang terdapat pada analisa deskriptif di mana terdapat atribut- atribut yang merupakan bagian dari analisa deskriptif.

Uji yang dipilih adalah Chi Square untuk melihat apakah ada hubungan antara variabel baris dengan kolom, yaitu karakteristik pengguna dengan persepsi tingkat kepuasan pengguna.
Tabel 2. Hasil Uji Validitas Instrumen Penelitian

\begin{tabular}{|l|r|r|r|r|c|}
\hline \multicolumn{7}{|c|}{ Item-Total Statistics } \\
\hline & $\begin{array}{c}\text { Scale Mean if } \\
\text { Item Deleted }\end{array}$ & $\begin{array}{c}\text { Scale } \\
\text { Variance if } \\
\text { Item Deleted }\end{array}$ & $\begin{array}{c}\text { Corrected } \\
\text { Item-Total } \\
\text { Correlation }\end{array}$ & $\begin{array}{c}\text { Squared } \\
\text { Multiple } \\
\text { Correlation }\end{array}$ & $\begin{array}{c}\text { Cronbach's } \\
\text { Alpha if Item } \\
\text { Deleted }\end{array}$ \\
\hline U1 & 75.3733 & 20.974 & .133 & .199 & .471 \\
U2 & 75.3533 & 21.317 & .065 & .224 & .483 \\
U3 & 76.3000 & 21.487 & .024 & .201 & .492 \\
U4 & 75.2333 & 21.106 & .099 & .161 & .477 \\
U5 & 76.3267 & 20.423 & .170 & .253 & .464 \\
U6 & 76.2133 & 20.384 & .200 & .145 & .458 \\
U7 & 76.1133 & 20.222 & .163 & .316 & .465 \\
U8 & 75.3867 & 20.695 & .190 & .177 & .461 \\
IQ9 & 75.3800 & 21.123 & .104 & .188 & .476 \\
IQ10 & 75.3667 & 20.596 & .186 & .164 & .461 \\
IQ11 & 76.3200 & 22.085 & .048 & .167 & .502 \\
IQ12 & 75.3733 & 22.115 & .049 & .192 & .501 \\
IQ13 & 75.3867 & 20.816 & .156 & .183 & .467 \\
IQ14 & 76.2800 & 21.505 & .028 & .203 & .490 \\
IQ15 & 75.2067 & 20.876 & .154 & .168 & .467 \\
S116 & 75.4200 & 21.306 & .091 & .067 & .477 \\
S117 & 75.4000 & 20.779 & .160 & .107 & .466 \\
S118 & 75.5000 & 21.326 & .092 & .145 & .477 \\
S119 & 75.3133 & 19.787 & .308 & .316 & .439 \\
S120 & 75.2533 & 20.794 & .169 & .265 & .465 \\
S121 & 76.2467 & 20.737 & .125 & .165 & .472 \\
S122 & 76.2667 & 20.318 & .196 & .170 & .458 \\
0123 & 75.6267 & 19.148 & .455 & .389 & .415 \\
\hline
\end{tabular}

Sumber : Pengolahan Kuesioner

Dari analisis output pada uji reabilitas di atas, bila dilihat kolom Corrected Item-Total Correlation merupakan nilai $\mathrm{r}$ hitung untuk masing- masing butir pertanyaan tiap varianel. Nilai $r$ hitung masing-masing butir pertanyaan positif dan nilainya lebih besar dari $\mathrm{r}_{\text {tabel, }}$ maka disimpukan $r_{\text {hitung }}>r_{\text {tabel }}$ alias butir pernyataan variabel dikatakan valid.

Tabel 3 Ringkasan Tabel Silang (Crosstab) untuk dimensi Usability

\begin{tabular}{|c|c|c|}
\hline $\begin{array}{c}\text { Dimensi } \\
\text { Usability }\end{array}$ & $\begin{array}{c}\text { Hasil Tabel Silang (Uji Crosstab) \& Uji } \\
\text { Chi Square }\end{array}$ & Hasil Analisis \\
\hline Pendidikan & Asymptot signifikan, yaitu 0,124>0,04 & H0 Diterima \\
\hline Kelamin & Asymptot signifikan, yaitu 0,798 >0,04 & H0 Diterima \\
\hline Usia & Asymptot signifikan, yaitu 0,952 >0,04 & H0 Diterima \\
\hline Pekerjaan & Asymptot signifikan, yaitu 0,086 $<0,04$ & $\begin{array}{c}\text { H1 Diterima (H0 } \\
\text { Ditolak) }\end{array}$ \\
\hline
\end{tabular}

Dari tabel 3 dapat diambil kesimpulan bahwa untuk Pendidikan, Kelamin, Usia, dan Pekerjaan tidak ada pengaruh atau hubungan terhadap dimensi Usability (HO Diterima). 
Tabel 4 Ringkasan Tabel Silang (Crosstab) untuk dimensi Interaction Quality

\begin{tabular}{|c|l|l|}
\hline $\begin{array}{l}\text { Dimensi } \\
\text { Information } \\
\text { Quality }\end{array}$ & $\begin{array}{l}\text { Hasil Tabel Silang (Uji Crosstab) \& Uji } \\
\text { Chi Square }\end{array}$ & \\
\hline Pendidikan & Asymptot signifikan, yaitu 0,318 $>0,04$ & H0 Diterima \\
\hline Kelamin & Asymptot signifikan, yaitu 0,477 $>0,04$ & H0 Diterima \\
\hline Usia & Asymptot signifikan, yaitu 0,403 >0,04 & H0 Diterima \\
\hline Pekerjaan & Asymptot signifikan, yaitu 0,737>0,04 & H0 Diterima \\
\hline
\end{tabular}

Dari tabel 4 dapat diambil kesimpulan bahwa untuk Pendidikan, Kelamin, Usia, dan Pekerjaan tidak ada pengaruh atau hubungan terhadap dimensi Interaction Quality (HO Diterima).

Tabel 5 Ringkasan Tabel Silang (Crosstab) untuk dimensi Services Interaction

\begin{tabular}{|c|l|c|}
\hline $\begin{array}{l}\text { Dimensi } \\
\text { Services } \\
\text { Interaction }\end{array}$ & $\begin{array}{l}\text { Hasil Tabel Silang (Uji Crosstab) \& Uji } \\
\text { Chi Square }\end{array}$ & Hasil Analisis \\
\hline Pendidikan & Asymptot signifikan, yaitu 0,904>0,04 & H0 Diterima \\
\hline Kelamin & Asymptot signifikan, yaitu 0,914>0,04 & H0 Diterima \\
\hline Usia & Asymptot signifikan, yaitu 0,468>0,04 & H0 Diterima \\
\hline Pekerjaan & Asymptot signifikan, yaitu 1,000>0,04 & $\begin{array}{l}\text { H1 Diterima } \\
\text { (H0 Ditolak) }\end{array}$ \\
\hline
\end{tabular}

Dari tabel 5 dapat diambil kesimpulan bahwa untuk Pendidikan, Kelamin, Usia, dan Pekerjaan tidak ada pengaruh atau hubungan terhadap dimensi Services Interaction (HO Diterima).

Tabel 6 Ringkasan Tabel Silang (Crosstab) untuk dimensi Overall Impression

\begin{tabular}{|c|c|c|}
\hline $\begin{array}{c}\text { Dimensi } \\
\text { Overall } \\
\text { Impression }\end{array}$ & $\begin{array}{c}\text { Hasil Tabel Silang (Uji Crosstab) \& Uji } \\
\text { Chi Square }\end{array}$ & Hasil Analisis \\
\hline Pendidikan & Asymptot signifikan, yaitu 0,168>0,04 & H0 Diterima \\
\hline Kelamin & Asymptot signifikan, yaitu $0,702>0,04$ & H0 Diterima \\
\hline Usia & Asymptot signifikan, yaitu $0,050>0,04$ & H0 Diterima \\
\hline Pekerjaan & Asymptot signifikan, yaitu $0,000<0,04$ & $\begin{array}{c}\text { H1 Diterima } \\
\text { (H0 Ditolak) }\end{array}$ \\
\hline
\end{tabular}

Dari tabel 6 dapat diambil kesimpulan bahwa untuk Pendidikan, Kelamin, Usia, dan Pekerjaan tidak ada pengaruh atau hubungan terhadap dimensi Overall Impression (HO Diterima).

\section{Uji One Sample t-Test}

Tabel 7. hasil Uji One Sample t-Test Instrumen Penelitian

\begin{tabular}{|c|c|c|c|c|c|c|}
\hline \multicolumn{7}{|c|}{ One-Sample Test } \\
\hline & \multirow[b]{2}{*}{$t$} & \multirow[b]{2}{*}{ df } & \multirow[b]{2}{*}{ Sig. (2-tailed) } & \multirow{2}{*}{$\begin{array}{l}\text { Mean } \\
\text { Difference }\end{array}$} & \multicolumn{2}{|c|}{$\begin{array}{l}95 \% \text { Confidence Interval of the } \\
\text { Difference }\end{array}$} \\
\hline & & & & & Lower & Upper \\
\hline U1 & 66.770 & 149 & .000 & 3.74667 & 3.6358 & 3.857 \\
\hline U2 & 63.422 & 149 & .000 & 3.76667 & 3.6493 & 3.884 \\
\hline U3 & 43.920 & 149 & .000 & 2.82000 & 2.6931 & 2.946 \\
\hline U4 & 66.186 & 149 & .000 & 3.88667 & 3.7706 & 4.002 \\
\hline U5 & 42.937 & 149 & .000 & 2.79333 & 2.6648 & 2.921 \\
\hline U6 & 47.786 & 149 & .000 & 2.90667 & 2.7865 & 3.026 \\
\hline U7 & 41.917 & 149 & .000 & 3.00667 & 2.8649 & 3.148 \\
\hline U8 & 69.051 & 149 & .000 & 3.73333 & 3.6265 & 3.840 \\
\hline 109 & 65.504 & 149 & .000 & 3.74000 & 3.6272 & 3.852 \\
\hline 1010 & 65.285 & 149 & .000 & 3.75333 & 3.6397 & 3.866 \\
\hline 1011 & 47.397 & 149 & .000 & 2.80000 & 2.6833 & 2.916 \\
\hline 1012 & 65.841 & 149 & .000 & 3.74667 & 3.6342 & 3.859 \\
\hline 1013 & 66.083 & 149 & .000 & 3.73333 & 3.6217 & 3.845 \\
\hline 1014 & 45.741 & 149 & .000 & 2.84000 & 2.7173 & 2.962 \\
\hline 1015 & 71.013 & 149 & .000 & 3.91333 & 3.8044 & 4.022 \\
\hline SI16 & 69.415 & 149 & .000 & 3.70000 & 3.5947 & 3.805 \\
\hline S117 & 65.432 & 149 & .000 & 3.72000 & 3.6077 & 3.832 \\
\hline S118 & 69.100 & 149 & .000 & 3.62000 & 3.5165 & 3.723 \\
\hline Sl19 & 64.689 & 149 & .000 & 3.80667 & 3.6904 & 3.922 \\
\hline $\mathrm{S} 120$ & 70.447 & 149 & .000 & 3.86667 & 3.7582 & 3.975 \\
\hline $\mathrm{S} \mid 21$ & 44.167 & 149 & .000 & 2.87333 & 2.7448 & 3.001 \\
\hline $\mathrm{S} 122$ & 45.274 & 149 & .000 & 2.85333 & 2.7288 & 2.977 \\
\hline 0123 & 63.569 & 149 & .000 & 3.49333 & 3.3847 & 3.601 \\
\hline
\end{tabular}

Pada bagian ini dilakukan analisis Uji One Sample t-Test yang terdiri dari :

1. Analisis :

- Hipotesis

H0 : Tidak ada kesenjangan pengguna akhir / end user laman Undhirabali.ac.id. H1 : Ada kesenjangan pengguna akhie / end user laman Undhirabali.ac.id.

- Pengambilan Keputusan

1. Berdasarkan perbandingan $t$ hitung dengan tabel: Ketentuan :

- H0 diterima : Jika $t_{\text {hitung }}$ berada di antara

nilai -ttabel dan + ttabel

- H0 ditolak : Jika thitung tidak berada

di antara nilai $-\mathrm{t}_{\mathrm{t}} \mathrm{a}_{\text {bel }} \mathrm{dan}+\mathrm{t}_{\text {tabel }}$.

Dari hasil tabel di atas, dengan tingkat signifikan (a) 5\% dengan df (derajat kebebasan) $=\mathrm{n}-1$, dibandingkan dengan $\mathrm{T}_{\text {hitung }}$ yang dilihat dari hasil nilai t. 
2. Berdasarkan nilai probabilitas

Ketentuan :

- Jika probabilitas > 0,05 maka H0 diterima ditolak

- Jika probabilitas $<0,05$ maka H1

\section{SIMPULAN}

Hasil evaluasi penelitian pengukuran kualitas website Universitas Dhyana Pura terhadap kepuasan pengguna yang telah dilakukan dari penelitian kali ini dapat disimpulkan bahwa secara umumnya adalah memuaskan dengan skor rata-rata 3,49, namun ada beberapa instrument di dalam 4 dimensi metode Webqual yang kurang memuaskan yaitu :

- U3 (3. Halaman situs web Universitas Dhyana Pura memiliki instruksi yang jelas)

- U5 (Situs web situs web Universitas Dhyana Pura memiliki tampilan desain / fitur yang menarik)

- U6 (Halaman situs web Universitas Dhyana Pura memiliki desain sesuai dengan jenis halaman (situs web akademik)

- IQ11 (halaman situs web Universitas Dhyana Pura memberikan informasi yang tepat waktu dan terkini)

- IQ14 (halaman situs web Universitas Dhyana Pura memberikan informasi terperinci dan lengkap)

- SI21 (halaman situs web Universitas Dhyana Pura memudahkan untuk berkomunikasi dengan organisasi dari halaman itu)

- SI22 (Situs web situs web Universitas Dhyana Pura memberi keyakinan bahwa layanan akan baik seperti yang dijanjikan)

\section{DAFTAR PUSTAKA}

[1] R. Hidayat, Cara praktis membangun website gratis, Jakarta: Elex Media Komputindo, 2010.

[2] I. Sanjaya, "Pengukuran Kualitas Layanan Website Kementrian KOMINFO dengan Menggunakan Metode Webqual 4.0," vol. 14, p. 1, 2012.
[3] "statshow.com," [Online]. Available: www.statshow.com. [Accessed 20 Agustus 2018].

[4] "Alexa," [Online]. Available: www.alexa.com. [Accessed 20 Agustus 2018].

[5] R. Vidgen and S. Barnes, "Assessing the Quality of a Cross-National eGovernment A Case study of the Forum on Strategic management knowledge exchange," in Hawai International Conference on System Sciences, Hawaii, 2003.

[6] H. Mediyawati. [Online]. [Accessed 18 September 2017].

[7] S. and D. O. Soemantri, "Pengukuran kulitas website dengan menggunakan metode webqual 4.0 (Studi Kasus : CV Zamrud Multimedia Network)," Jurnal Rekayasa dan Manajemen Sistem Informasi, vol. 2, 2016.

[8] P. Kotler and K. L. Keller, Manajemen Pemasaran Edisi 12., Jakarta: PT. Indeks, 2007.

[9] A. Gregorius, Tips \& Trik Membuat Efek Spesial Website dengan Dreamweaver 4, Jakarta: PT. Elex Media KOmputindo, 2000.

[10] J. Supranto, Pengukuran Tingkat Kepuasan Pelanggan untuk Menaikkan Pangsa Pasar, Jakarta: T. Rineka Cipta., 2006.

[11] H. Park and S. Baek, "Springer-Verlag Berlin Heidelberg," Measuring Service Quality of Online Bookstores with Webqual, vol. 4553, pp. 95-103, 2007.

[12] S. Statistika Untuk Usulan Penelitian, Bandung: CV. Alfabeta, 2010.

[13] D. Sunyoto, Statistika Deskriptif dan Probabilitas Edisi 1, Yogyakarta: CAPS (Centrer for Academic Publishing Services), 2016.

[14] a. taufik and h. goerge, "website," 2012. [Online]. Available: www.abc.com. [Accessed 20 agustus 2018]. 